\title{
The use of two-dimensional electrophoresis in the characterization of the water-soluble protein fraction of commercial flat fish species
}

\author{
Carmen Piñeiro - Jorge Barros-Velázquez - Carmen G. Sotelo - José M. Gallardo \\ C. Piñeiro - J. Barros-Velázquez ${ }^{1}$ - C.G. Sotelo - J.M. Gallardo \\ Departamento de Química y Tecnología de Productos Marinos, Instituto de \\ Investigaciones Marinas (CSIC), Eduardo Cabello 6, E-36208 Vigo, Spain \\ e-mail: cpineiro@iim.csic.es \\ ${ }^{1}$ Present address: \\ Laboratorio de Tecnología de Alimentos, Escuela Politécnica Superior, Universidad de \\ Santiago de Compostela, E-27002 Lugo, Spain
}

\begin{abstract}
The water-soluble proteins of nine flat fish species of high commercial value, belonging to the Pleuronectidae, Scophtalmidae, and Soleidae families, were analyzed by twodimensional (2D) electrophoresis, this being carried out by nondenaturing isoelectric focusing (IEF) in the 3.5-9.5 pH range and gradient SDS-PAGE in the 12-14\% range. Most of the major proteins fell in the 3.5-6.9 pH range. From these, the most specific proteins were in the acidic fraction $(\mathrm{p} I<5.2 ; \mathrm{MW}<16 \mathrm{kDa}$ ). Species-specific 2D protein patterns were observed in all the nine species, and more than 25 proteins could be individualized. The combination of nondenaturing IEF and gradient SDSPAGE, both in the absence of urea, allowed detailed characterization of both the isoelectric points and molecular weights of the major water-soluble proteins and proved to be a valuable tool for the differential characterization of the flat fish species studied.
\end{abstract}

Key words Two-dimensional electrophoresis - Isoelectric focusing - Flat fish - Protein Identification - Differential characterization

Introduction 
Flat fish, belonging to the Heterosomata order, comprise a group of fish species of high commercial value that are used not only for fresh consumption but also in the fishprocessing industry [1]. The processing of fish in the seafood industry to obtain a wide range of seafood products involves not only the handling of whole flat fish specimens but also the manipulation of fillets or minced fish. The processed fish material does not retain the anatomical features of the fish, thus complicating the unambiguous identification of the fish species. In an effort to overcome fraudulent practices like the substitution of a fish species by others of less commercial value, labeling regulations have been imposed on seafood products by many countries [2-5]. As a consequence of this, the development of robust analytical techniques aimed at achieving a precise identification and characterization of fish species in both raw and processed fish material is gaining increasing importance. Thus, several techniques based on biochemical methods have been advanced as powerful tools for the identification of species in whole raw fish and in seafood products [5, 6]. Among these methods, highperformance liquid chromatography [7-10], isoelectric focusing (IEF) [11-15], capillary zone electrophoresis [16], and the amplification of selected DNA sequences by the polymerase chain reaction $[17,18]$ have been applied to the identification of certain groups of fish species.

Analysis of muscle proteins by two-dimensional (2D) electrophoresis has been recently applied to the study of certain fish species [19, 20], but, to our knowledge, 2D electrophoresis has not been extensively applied to the characterization of fish species. The determination of the $\mathrm{pI}$ and MW values of the water-soluble protein fraction by 2D electrophoresis would allow more complete protein characterization than by IEF alone, since two proteins from different species with apparently identical pI values as determined by one-dimensional analysis (IEF) may probably be distinguished by size. Thus, the purpose of this work was to adapt a 2D electrophoresis protocol in the absence of urea to the characterization of nine flat fish species of high commercial value. Unlike other 2D protocols, this strategy allowed us to determine both the isoelectric point $(\mathrm{p} I)$ and molecular weight (MW) of the major water-soluble proteins. Additionally, we carried out a comparative analysis of the 2D protein patterns with the purpose of distinguishing among apparently identical water-soluble proteins as determined by IEF alone. 
Materials and methods

Fish material

Nine different flat fish species belonging to the Pleuronectidae (six), Scophtalmidae (two), and Soleidae (one) families were considered in this study (Table 1). Whole specimens of these species were purchased at a local market as fresh fish, except for Hippoglossus hippoglossus, Limanda limanda, Platichthys flesus, and Pleuronectes platessa, which were caught in other fishing banks and shipped frozen by overnight delivery. Two batches of Platychthys flesus belonging to different geographical locations were studied. Likewise, two batches of Pleuronectes platessa from two geographical locations were considered. The whole fish specimens were the subject of taxonomical study according to their anatomical and morphological features. Three specimens of each fish species were used in this study.

Preparation of water-soluble protein extracts

Representative portions of $5 \mathrm{~g}$ of muscle were obtained from each fish specimen, minced, and mixed with $10 \mathrm{ml}$ of distilled water for $3 \mathrm{~min}$ - with interruptions of $30 \mathrm{~s}$ to avoid warming the samples - by using an Ultra-Turrax homogenator device. Then, the mixture was spun at $4{ }^{\circ} \mathrm{C}$ for $15 \mathrm{~min}$ at $12500 \mathrm{~g}$. The supernatants were recovered, filtered, and kept at $-80^{\circ} \mathrm{C}$ until the electrophoretic analyses were carried out. The protein concentrations in the extracts were determined by the bicinconinic acid (BCA) method from Pierce Laboratories (Rockford, Ill.). When required, the water-soluble protein extracts were heated in a water bath at $100{ }^{\circ} \mathrm{C}$ for $5 \mathrm{~min}$. Then, the extracts were cooled, spun at $12000 \mathrm{~g}$ for $5 \mathrm{~min}$, and the supernatants processed by IEF as described below.

Two-dimensional electrophoretic analysis of flat fish species

Isoelectric focusing. This was carried out at $15{ }^{\circ} \mathrm{C}$ in a refrigerated Multiphor II electrophoresis unit from Pharmacia Biotech Europe (Uppsala, Sweden). Precast polyacrylamide 245x110x1 mm gels (Ampholine PAGplate, $\mathrm{pH}$ 3.5-9.5) for analytical IEF were employed. The anode and cathode Solutions were $1 \mathrm{M} \mathrm{H}_{3} \mathrm{PO}_{4}$ and $1 \mathrm{M} \mathrm{NaOH}$, 
respectively. Ten to fifteen mg of protein were loaded on each sample applicator paper. Run conditions were as follows: $1500 \mathrm{~V}, 50 \mathrm{~mA}, 30 \mathrm{~W}$ until at least $4000 \mathrm{~V} / \mathrm{h}$ were reached. One-dimension IEF gels were stained with 0.1\% Coomassie Blue (Merck) according to the Pharmacia- Biotech staining protocol. A mixture of protein standards in the 3.5-9.3 pH range (broad $\mathrm{pI}$ calibration kit from Pharmacia Biotech) was included in the IEF gels. When required, IEF strips corresponding to individual lanes were not stained and kept frozen at $-80{ }^{\circ} \mathrm{C}$ for later analysis by 2D SDS-PAGE.

Two-dimensional analysis by gradient SDS-PAGE. Equilibration of IEF strips was carried out prior to 2D analysis by placing the IEF strips for $10 \mathrm{~min}$ in Laemmli sample buffer [21] containing $0.75 \%$ dithiothreitol and then for another $10 \mathrm{~min}$ in Laemmli sample buffer containing $4.5 \%$ iodoacetamide. Once equilibrated, the strips were processed by 2D gradient SDS-PAGE at $15^{\circ} \mathrm{C}$ in the Multiphor II electrophoresis system (Pharmacia Biotech). Precast polyacrylamide 245x180x0.5 mm gradient gels (Excel-Gel XL SDS 12-14, Pharmacia Biotech) for horizontal electrophoresis were employed. Anode and cathode buffer strips (Excel-Gel SDS Buffer Strips, Pharmacia Biotech) were used. A mixture of protein standards of low molecular weight in the 14$67 \mathrm{kDa}$ range (Pharmacia Biotech) was employed as reference. Run conditions were as follows: $1000 \mathrm{~V}, 20 \mathrm{~mA}, 40 \mathrm{~W}$ for $45 \mathrm{~min}$, followed by $1000 \mathrm{~V}, 40 \mathrm{~mA}, 40 \mathrm{~W}$ for 150 min. Once the bromophenol blue had reached the anode, the gels were fixed and stained by a standard silver staining protocol (Pharmacia Biotech).

\section{Data processing}

Both the MW and $\mathrm{PI}$ of the proteins obtained by IEF and 2D SDS-PAGE, respectively, were determined by using the Whole Band Analyzer Software (BioImage Systems, Mich.) in a Sun SPARCstation 5 (Sun Microsystems) equipped with a Scanmaster 3+ device (Howtek, N.H.), and the corresponding $\mathrm{p} I$ and MW calculated by comparison with respect to the protein standards.

Results and discussion 
The first goal of this work was to obtain and compare the water-soluble protein profiles of the selected flat fish species by IEF. Although the $\mathrm{pH}$ range in the IEF gels was broad (3.5-9.5), the majority of the extracts displayed the most characteristic protein bands in the $3.5-6.9 \mathrm{pH}$ range (Fig. 1).

Water-soluble extracts prepared from two batches of the species Platychthys flesus, caught in distant geographical locations, displayed similar protein patterns, although some discordances were characterized in the 5.7-6.2 $\mathrm{pH}$ range. Thus, a protein with a $\mathrm{pI}$ of 6.2 was present in only one specimen (Fig. 1, lane 3) and a protein with $\mathrm{p} I=5.8$ was only present in the other (Fig. 1, lane 4). Additionally, the water-soluble protein patterns of two batches of Pleuronectes platessa from two different geographical locations were studied by IEF, and no significant difference between the protein patterns was detected (Fig. 1, lanes 5 and 6).

Both species of the Scophtalmidae family studied - megrim and turbot - displayed a characteristic pair of protein bands in the 6.3-6.4 pH range (Fig. 1, lanes 9 and 10) that was not observed in any of the other flat fish species studied. Additionally, Limanda limanda, H. hippoglossus, Glyptocephalus cynoglossus, Pleuronectes cynoglossus, and Solea solea showed species-specific protein patterns (Fig. 1).

It is remarkable that several of the species-characteristic proteins are observed in the anodic side of the gel (Fig. 1), in the $\mathrm{pH}$ region below 5.2. This protein fraction would include the parvalbumins, a group of proteins of high acidic nature, small size, and with a remarkable heat-resistance [22-25], this being a property that makes them extremely interesting in the investigation of samples obtained from heat-processed fish samples. The $\mathrm{pI}$ values of the heat-resistant proteins were determined by IEF analysis of the protein extracts after heating for $5 \mathrm{~min}$ at $100{ }^{\circ} \mathrm{C}$ (Fig. 1 , lanes 1 to $11^{\prime}$ ).

As a result of the analysis of the water-soluble protein fraction of the flat fish species by IEF, the following strategy was considered: (1) only one batch of Pleuronectes platessa (Fig. 1, lane 5) was further investigated by 2D electrophoresis, since this was identical to the other batch analyzed by IEF; (2) both batches of Platychthys flesus (Fig. 1, lanes $3-4$ ) were subjected to $2 \mathrm{D}$ analysis owing to the differences observed in their IEF 
protein profiles; (3) all the other seven flat fish species were further studied by 2D electrophoresis.

Two-dimensional electrophoretic analysis of water-soluble proteins

Although complex, 2D electrophoresis allowed not only the obtainment of speciesspecific 2D patterns for all the species tested, but also the separation of the major watersoluble proteins and the determination of their $\mathrm{pI}$ and $\mathrm{MW}$, relevant for both basic and applied research. Special interest was focused on the heat-resistant protein fraction (Fig. 1 , lanes $1^{\prime}$ ' to $11^{\prime}$ ), which was determined in the 2D diagrams by detailed comparison of the IEF and 2D gels (Figs. 1 and 2, respectively).

H. hippoglossus, halibut, did not display major proteins in the cathodic left side of the 2-D gels (6.6-9.5 pH range) (Fig. 2a), a result that was not observed in any of the other flat fish species tested. Only one characteristic major protein (Fig. 2a, protein 1) of large size - $97 \mathrm{kDa}$ - and pIp6.6 was observed, while at least six moderately acidic proteins appeared in the 35-66 kDa interval (Fig. 2a, proteins 2-7). Four major acidic proteins of low MW, previously characterized as heat resistant (Fig. 1, lane $1^{\prime}$ ), were observed in halibut (Fig. 2a, proteins 8-11); their corresponding $\mathrm{p} I$ values and MW are compiled in Table 2.

Limanda limanda, common dab, displayed one major protein (Fig. 2b, protein 1) with a $\mathrm{pI}$ of 5.6 and a MW of $96 \mathrm{kDa}$. The central region of the 2D electrophoretic pattern (29$65 \mathrm{kDa}$ interval and 5.7-7.6 pH range) displayed at least six major proteins (Fig. 2b, proteins 2-7). With respect to the anodic side of the gel, at least six proteins, five of them previously determined as heat resistant (Fig. 1, lane 2'), were observed (Fig. 2b, proteins 8-13). The $\mathrm{p} I$ values and MW of the major heat-resistant proteins of common dab are compiled in Table 2.

Two different specimens of Platichthys flesus, flounder, from distant fishing banks were investigated by 2D electrophoresis and were apparently identical (Figs. 2c and 2d, respectively). Thus, major proteins of $\mathrm{p} I=6.0$ and with $\mathrm{MW}$ of $96 \mathrm{kDa}$ (protein 1 from Figs. 2c and 2d, respectively) were observed in the upper region of the 2D electrophoretic diagrams. Five major proteins (Figs. 2c and 2d, proteins 2-6, 
respectively) were observed in the central region of the gels (38-54 kDa interval and 5.3-7.5 pH range). It is also remarkable that proteins 7-9, all of them in the 5.4-5.6 pH range, displayed sizes in the $17 \mathrm{kDa}$ to $27 \mathrm{kDa}$ interval, although these proteins were not heat resistant (Fig. 1, lanes 3-3' and 4-4'). With respect to the heat-resistant proteins that had been observed in both batches of Platychthys flesus (Fig. 1, lanes 3' and 4'), their MWs were determined by 2D electrophoresis (Figs. 2c, d, proteins 10-13, respectively); the results are compiled in Table 2.

Only one of the two batches of Pleuronectes platessa, plaice, was subject to 2D electrophoretic study. A single major protein (Fig. 2e, protein 1) with $\mathrm{pI} 5.9$ and am MW of $95 \mathrm{kDa}$ was observed in the region corresponding to the high molecular weight proteins. Six major proteins (Fig. 2e, proteins 2-7) were observed in the 37-60 kDa and 5.3-7.5 pH ranges. Additionally, protein 8 (Fig. 2e) displayed a $\mathrm{pI}$ of ca. 6.7 and a MW of $29 \mathrm{kDa}$. The lower gel region (10-18 kDa interval and 3.5-5.2 $\mathrm{pH}$ range) was characterized by the presence of at least six major proteins (Fig. 2e, proteins 9-14), some of them being heat resistant (Fig. 1, lane 5'). The data obtained for the heatresistant fraction of plaice are compiled in Table 2.

G. cynoglossus, witch, displayed one major protein (Fig. 2f, protein 1) with a pI of 5.6 and a size of $94 \mathrm{kDa}$ in the upper gel region, while the central part of the 2D electrophoretic protein pattern (35-60 kDa interval and 5.3-7.6 pH range) was characterized by the presence of at least 11 major proteins (Fig. 2f, proteins 2-12). Likewise, the region in the 3.5-5.2 $\mathrm{pH}$ range was rich in protein spots (Fig. 2f, proteins 13-23), all of them, except for protein 13 (MW $27 \mathrm{kDa}$ ) ranging in the 10.5-17 kDa interval. Proteins 14-23 (Fig. 2f) - displaying a remarkable acidic nature - allowed us to compose a species-specific protein pattern. From these, the heat-resistant fraction was identified by comparing the protein spots in Fig. $2 \mathrm{f}$ with the data afforded by the IEF study (Fig. 1, lane 7'). The data obtained for the heat-resistant protein fraction of witch are compiled in Table 2.

Pleuronectes cynoglossus, witch flounder, displayed a single protein - protein 1 - with a $\mathrm{pI}$ of 6.0 and a MW of $94 \mathrm{kDa}$ in the upper gel region, while the central part of the 2D electrophoretic pattern (36-62 kDa interval and 5.5-8.0 pH range) displayed about 15 major proteins (Fig. 2 g, proteins 2-16). The presence of a major protein of $\mathrm{pI} 4.9$ and 9 
$\mathrm{kDa}$ in size was remarkable (Fig. 2 g, protein 21). Additionally, at least four acidic proteins (Fig. 2 g, proteins 17-20) were observed. The pI value and MW of these five proteins, previously characterized as heat resistant (Fig. 1, lane 8'), are summarized in Table 2.

Two flat fish belonging to the Scophtalmidae family, namely Lepidorhombus whiffiagonis, megrim, and Scophtalmus maximus, turbot, were studied by 2D electrophoresis. The protein patterns observed for both species were quite similar in both the upper and middle MW ranges (Figs. 2h, i). Thus, proteins 1 (94 kDa and pI 5.6) and 2 (89 kDa and $\mathrm{pI}$ 6.1) seemed to be identical in both species (Figs. 2h, i). The presence of this pair of proteins in the high MW region was characteristic of these two species, and was not observed in any of the other flat fish studied. Additionally, both species showed a characteristic pair of proteins (proteins 4-5) of $48 \mathrm{kDa}$ in the 6.3-6.4 pH range (Figs. 2h, i). About 10 major proteins (proteins 3-12) were observed in the 34-67 kDa interval and 5.4-8.0 pH range in megrim and turbot (Figs. 2h, i). It is also remarkable that protein 13 (pI 5.1) from megrim had a size of $26 \mathrm{kDa}$ (Fig. 2h), while protein 13 (pI 5.1) from turbot showed a MW of ca. $11 \mathrm{kDa}$ (Fig. 2i). The acidic protein fraction of turbot (proteins 14-17) was quite different and more complex than that observed in megrim (proteins 16-18). The $\mathrm{pI}$ values and MW of the heat-resistant proteins of megrim and turbot are compiled in Table 2.

Solea solea, sole, displayed a major protein (Fig. 2j, protein 1) with a $\mathrm{pI}$ of 5.9 and a size of $91 \mathrm{kDa}$ in the upper gel region. As in other species tested, most of the major proteins (Fig. 2j, proteins 2-9) were observed in the central region of the gel, and were in all cases in the 37-60 kDa interval and in the 5.4-8.0 pH range. Three speciesspecific acidic proteins with $\mathrm{p} I$ values below 5.2, previously determined as heat resistant (Fig. 1, lane 11'), were observed in the 5-12 kDa interval (Fig. 2j, proteins 12-14) and their corresponding $\mathrm{p} I$ values and MW are compiled in Table 2.

In conclusion, IEF in the absence of urea allowed us to characterize the $\mathrm{p} I$ values of the major water-soluble proteins in the flat fish studied and to distinguish among species of high commercial value. The results obtained in this work also allowed us to obtain 2D protein patterns in which more than 25 different proteins could be observed for each species, most of them being in the 35-65 kDa and 3.5-6.9 pH ranges. The acidic 
fraction was species-specific and conformed to characteristic protein patterns in the 5$16 \mathrm{kDa}$ interval and 3.5-5.2 $\mathrm{pH}$ range (Table 2). Among the proteins with a marked acidic nature, the heat-resistant proteins were identified and the $\mathrm{p} I$ and $\mathrm{MW}$ values determined. The relevance of these proteins is significant since they are accurate indicators to be followed both in raw and heat-processed fish [22]. 2D electrophoresis thus proved to be a valuable tool for the characterization of the water-soluble protein fraction from flat fish species of commercial interest and may be helpful, in addition to IEF, for distinguishing among apparently identical proteins from closely related species.

\section{Acknowledgements}

The authors thank the financial support of CICYT (Project ALI95-0053). The authors thank the Instituto Español de Oceanografía (IEO) for the anatomical study, and Helena Pazó for her excellent technical assistance.

References

1. Dann N (1997) J Sea Res 37: 321-341

2. Hensley DA (1997) J Sea Res 37: 187-194

3. Mermelstein MH (1993) Food Technol 47: 81-96

4. Smith D (1991) Trends Food Sci Technol 2:236-240

5. Mackie IM (1998) Authenticity of fish. In:Ashurst PR, Dennis MJ (eds) Food authentication. Chapman \& Hall, London, pp 140-170

6. Sotelo CG, Piñeiro C, Gallardo JM, Pérez-Martín RI (1993) Trends Food Sci Technol $4: 395-401$

7. Armstrong G, Leach DN (1992) Food Chem 44:147-155

8. Ashoor SH, Knox MJ (1985) J Chromatogr 324:199-202

9. Osman MA, Ashoor SH, Marsh PC (1987) J Assoc Off Anal Chem 70:618-625

10. Piñeiro C, Sotelo CG, Medina I, Gallardo JM, Pérez-Martín RI (1997) Z Lebensm Unters Forsch 204: 411-416

11. Rehbein H (1990) Z Lebensm Unters Forsch 191: 1-10

12. Rehbein H, Kündiger H (1984) Arch Fischwiss 35: 7-16

13. Mackie IM (1980) The use of electrophoresis of the water-soluble muscle proteins in the quantitative analysis of the species components of a fish mince mixture. 
In:Connell JJ (ed) Advances in fish Science and technology. Fishing News Books, Fishing News Book, Farnham, Surrey, England, pp 444-451

14. Malmheden I (1992) Eur Food Drink Rev, Pharmacia Biotech Readers Enquiry No 36 (autumm issue)

15. Sotelo CG, Piñeiro C, Gallardo JM, Pérez-Martín RI (1992) Z Lebensm Unters Forsch 195:224-227

16. Gallardo JM, Sotelo CG, Piñeiro C, Pérez-Martín RI (1995) J Agric Food Chem 43:1238-1244

17. Rehbein H, Mackie IM, Pryde S, González-Sotelo C, Pérez-Martín R, Quinteiro J, Rey-Méndez M (1995) Inf Fischwirtsch 42:209-212

18. Quinteiro J, Sotelo CG, Rehbein H, Pryde SE, Medina I, Pérez- Martín RI, ReyMéndez M, Mackie IM (1998) J Agric Food Chem 46: 1662-1669

19. Martínez I, Christiansen JS (1993) Comp Biochem Physiol B 107:11-20

20. Martínez I, Solberg C, Lauritzen K, Ofstad R (1992) Appl Theor Electrophor 2: 201-206

21. Laemmli UK (1970) Nature 227: 680-685

22. Shaklee JB, Keenan CP (1986) A practical laboratory guide to techniques and methodology of electrophoresis and its application to fish fillet identification. CSIRO, Melbourne

23. Capony JP, Pechère JF (1973) Eur J Biochem 32: 88-96

24. Closset JI (1976) Comp Biochem Physiol 55:531-535

25. Closset JI, Gerday Ch (1976) Comp Biochem Physiol 55:537-542 
Table 1 Flat fish species considered in this study

\begin{tabular}{|l|l|}
\hline Species & Common name \\
\hline Hippoglossus hippoglossus & Halibut \\
\hline Limanda limanda & Common dab \\
\hline Platichthys flesusa & Flounder \\
\hline Pleuronectes platessaa & Plaice \\
\hline Glyptocephalus cynoglossus & Witch \\
\hline Pleuronectes cynoglossus & Witch flounder \\
\hline Lepidorhombus whiffiagonis & Megrim \\
\hline Scophthalmus maximus & Turbot \\
\hline Solea solea & Sole \\
\hline
\end{tabular}

a Specimens from two different geographical locations were studied

Table 2 Heat-resistant proteins present in the nine flat fish species studied

\begin{tabular}{|c|c|c|c|c|c|c|c|}
\hline Fish species & Protein $^{2}$ & $\mathrm{pI} / \mathrm{MWb})$ & & & & & \\
\hline $\begin{array}{l}\text { Hippoglossus } \\
\text { hippoglossus }\end{array}$ & $\begin{array}{l}10 \\
(4.1 / 13)\end{array}$ & $\begin{array}{l}11 \\
(3.9 / 11)\end{array}$ & & & & & \\
\hline $\begin{array}{l}\text { Limanda } \\
\text { limanda }\end{array}$ & $\begin{array}{l}9 \\
(4.3 / 16)\end{array}$ & $\begin{array}{l}10 \\
(3.9 / 15)\end{array}$ & $\begin{array}{l}11 \\
(4.1 / 13)\end{array}$ & $\begin{array}{l}12 \\
(3.8 / 13)\end{array}$ & $\begin{array}{l}13 \\
(4.0 / 12)\end{array}$ & & \\
\hline $\begin{array}{l}\text { Platichthys } \\
\text { flesus }\end{array}$ & $\begin{array}{l}10 \\
(4.0 / 16)\end{array}$ & $\begin{array}{l}11 \\
(4.1 / 15)\end{array}$ & $\begin{array}{l}12 \\
(3.8 / 9)\end{array}$ & $\begin{array}{l}13 \\
(3.5 / 8)\end{array}$ & & & \\
\hline $\begin{array}{l}\text { Pleuronectes } \\
\text { platessa }\end{array}$ & $\begin{array}{l}11 \\
(4.1 / 17)\end{array}$ & $\begin{array}{l}12 \\
(4.3 / 16)\end{array}$ & $\begin{array}{l}13 \\
(3.7 / 14)\end{array}$ & $\begin{array}{l}14 \\
(3.5 / 10)\end{array}$ & & & \\
\hline $\begin{array}{l}\text { Glyptocephalus } \\
\text { cynoglossus }\end{array}$ & $\begin{array}{l}17 \\
(3.9 / 16)\end{array}$ & $\begin{array}{l}18 \\
(3.7 / 16)\end{array}$ & $\begin{array}{l}19 \\
(3.9 / 11)\end{array}$ & $\begin{array}{l}20 \\
(3.8 / 11)\end{array}$ & $\begin{array}{l}21 \\
(3.6 / 11)\end{array}$ & $\begin{array}{l}22 \\
(3.5 / 12)\end{array}$ & $\begin{array}{l}23 \\
(3.4 / 12)\end{array}$ \\
\hline $\begin{array}{l}\text { Pleuronectes } \\
\text { cynoglossus }\end{array}$ & $\begin{array}{l}17 \\
(4.1 / 16)\end{array}$ & $\begin{array}{l}18 \\
(4.0 / 16)\end{array}$ & $\begin{array}{l}19 \\
(3.7 / 14)\end{array}$ & $\begin{array}{l}20 \\
(3.5 / 13)\end{array}$ & $\begin{array}{l}21 \\
(4.4 / 9)\end{array}$ & & \\
\hline $\begin{array}{l}\text { Lepidorhombus } \\
\text { whiffiagonis }\end{array}$ & $\begin{array}{l}16 \\
(4.1 / 12)\end{array}$ & $\begin{array}{l}17 \\
(3.8 / 5)\end{array}$ & $\begin{array}{l}18 \\
(3.5 / 5)\end{array}$ & & & & \\
\hline $\begin{array}{l}\text { Scophthalmus } \\
\text { maximus }\end{array}$ & $\begin{array}{l}14 \\
(4.1 / 11)\end{array}$ & $\begin{array}{l}15 \\
(3.8 / 7)\end{array}$ & $\begin{array}{l}16 \\
(3.5 / 7)\end{array}$ & $\begin{array}{l}17 \\
(3.4 / 8)\end{array}$ & & & \\
\hline Solea solea & 12 & 13 & 14 & & & & \\
\hline
\end{tabular}




\begin{tabular}{|l|l|l|l|l|l|l|l|}
\hline & $(4.5 / 12)$ & $(3.8 / 5)$ & $(3.5 / 5)$ & & & & \\
\hline
\end{tabular}

a The proteins are numbered according to the order in Fig. 2

b MW in kDa

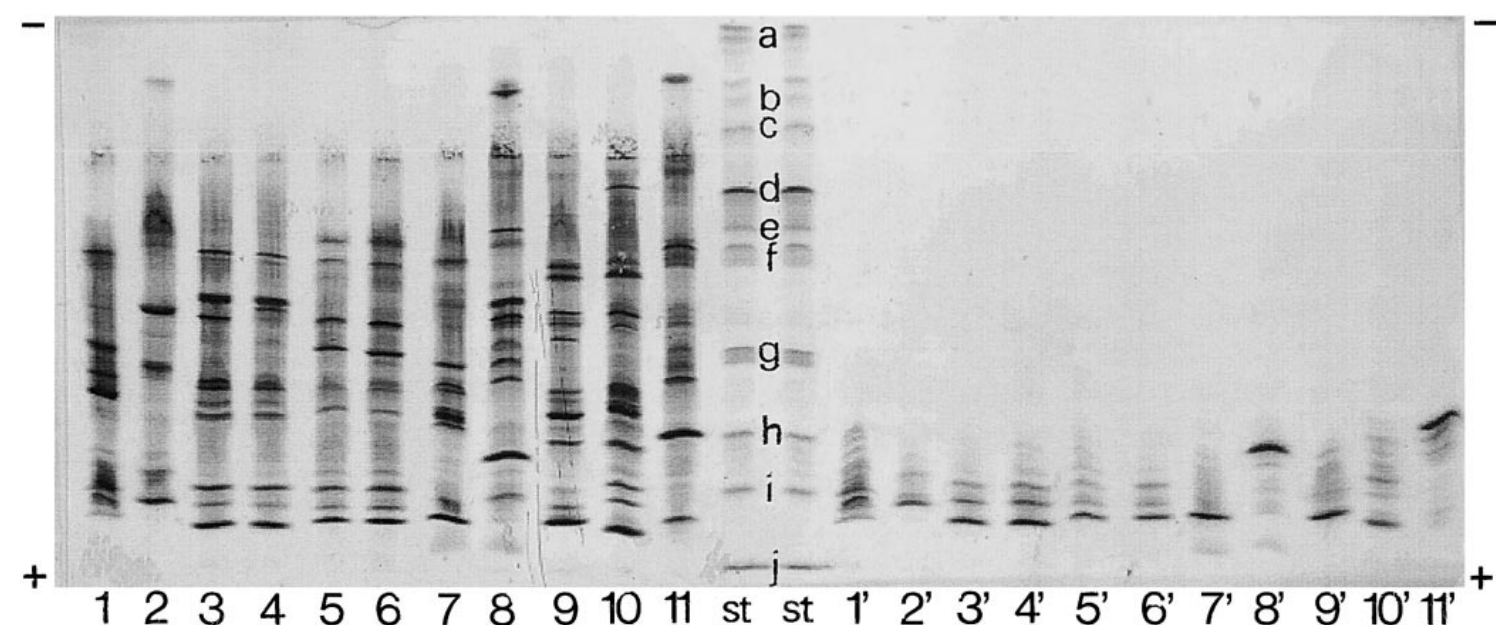

Fig. 1 Isoelectric focusing (3.5-9.5 pH range) of the water-soluble proteins in the flat fish species studied. Lane 1: Hippoglossus hippoglossus; Lane 2:Limanda limanda; lane 3: Platychthys flesus; lane 4: Platychthys flesus; lane 5: Pleuronectes platessa; lane 6: Pleuronectes platessa; lane 7: Glyptocephalus cynoglossus; lane 8:Pleuronectes cynoglossus; lane 9: Lepidorhombus whiffiagonis; lane 10: Scophtalmus maximus; lane 11: Solea solea. The heatprocessed corresponding counterparts follow the same order, from lane 1' to lane 11 '. st: isoelectric focusing standard; the $\mathrm{p} I$ values corresponding to the protein standards are as follows: $a: 9.3 ; b: 8.45 ; c: 8.15 ; d: 7.55 ; e: 6.85 ; f: 6.55 ; g$ : 5.85; $h: 5.2 ; i: 4.55 ; j: 3.5$. The cathodic (-) and anodic (c) sides are indicated 


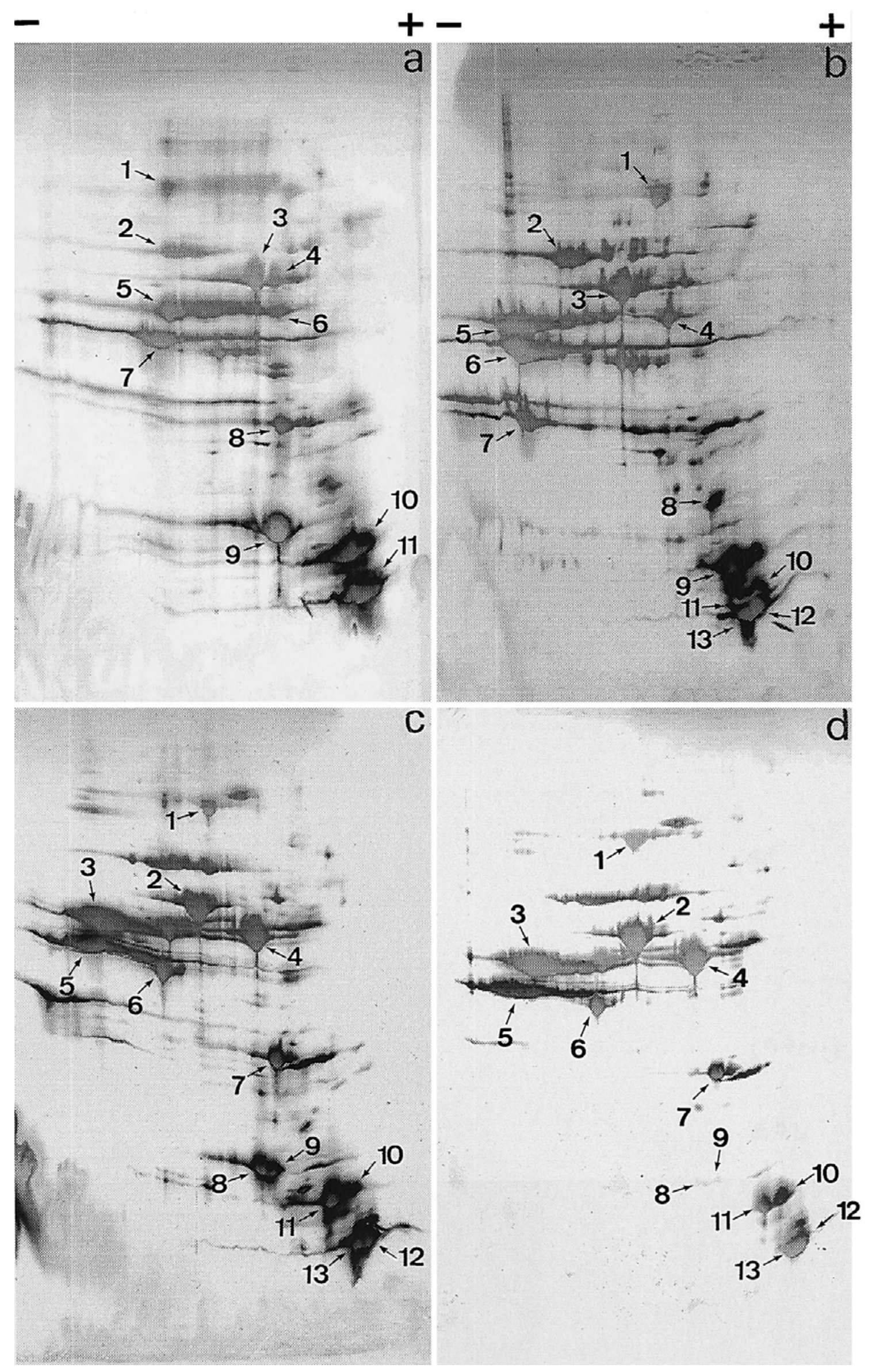


Fig. 2 a-j Two-dimensional electrophoretic analysis of the water-soluble protein fraction. a Hippoglossus hippoglossus; b Limanda limanda; c Platychthys flesus; d Platychthys flesus; e Pleuronectes platessa; f Glyptocephalus cynoglossus; g Pleuronectes cynoglossus; $\mathbf{h}$ Lepidorhombus whiffiagonis; I Scophtalmus maximus; j Solea solea. Major proteins referred to in the text are indicated with black arrows. The cathodic (-) and anodic (c) sides are indicated 


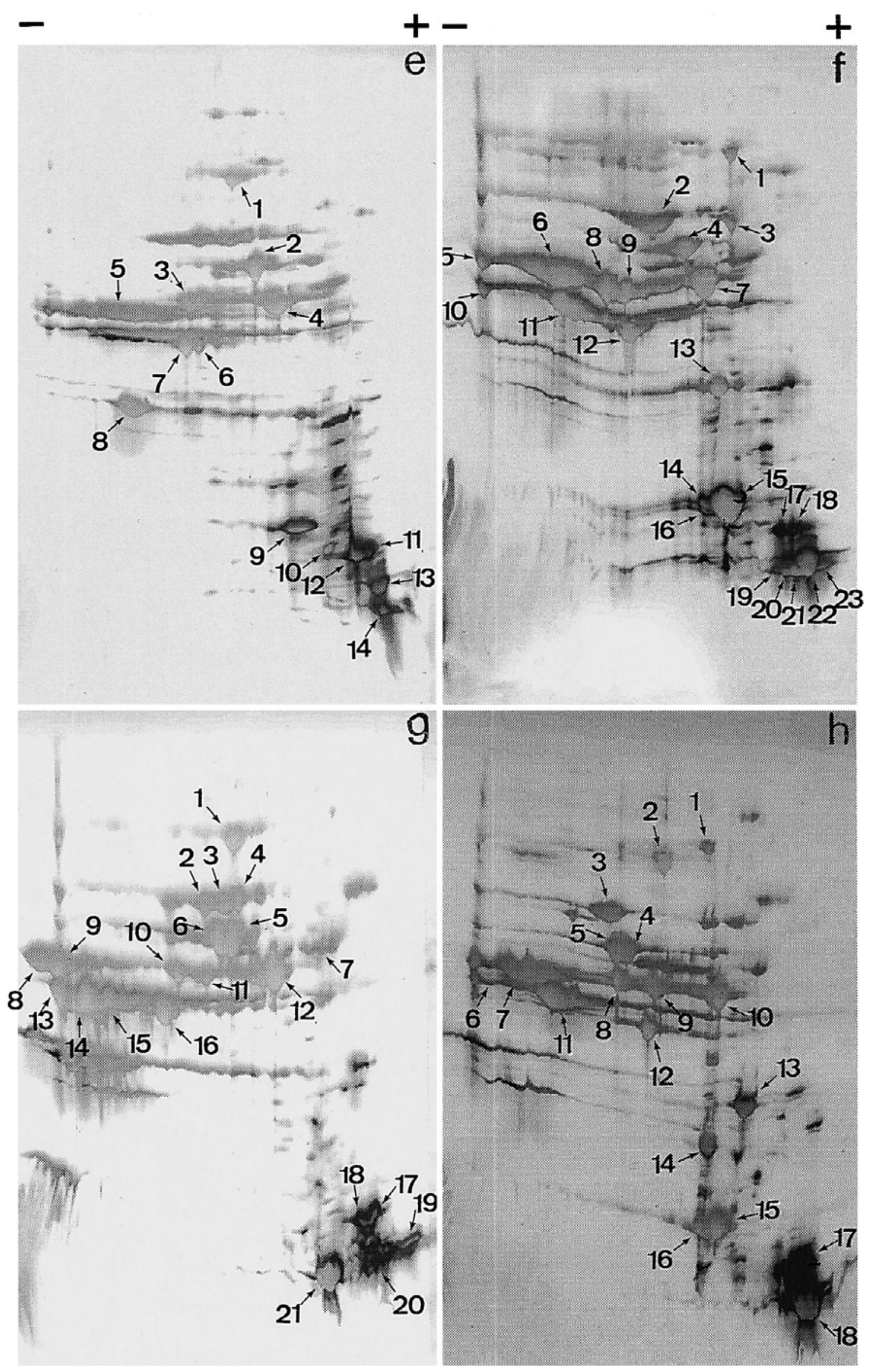

Fig. 2e-h 


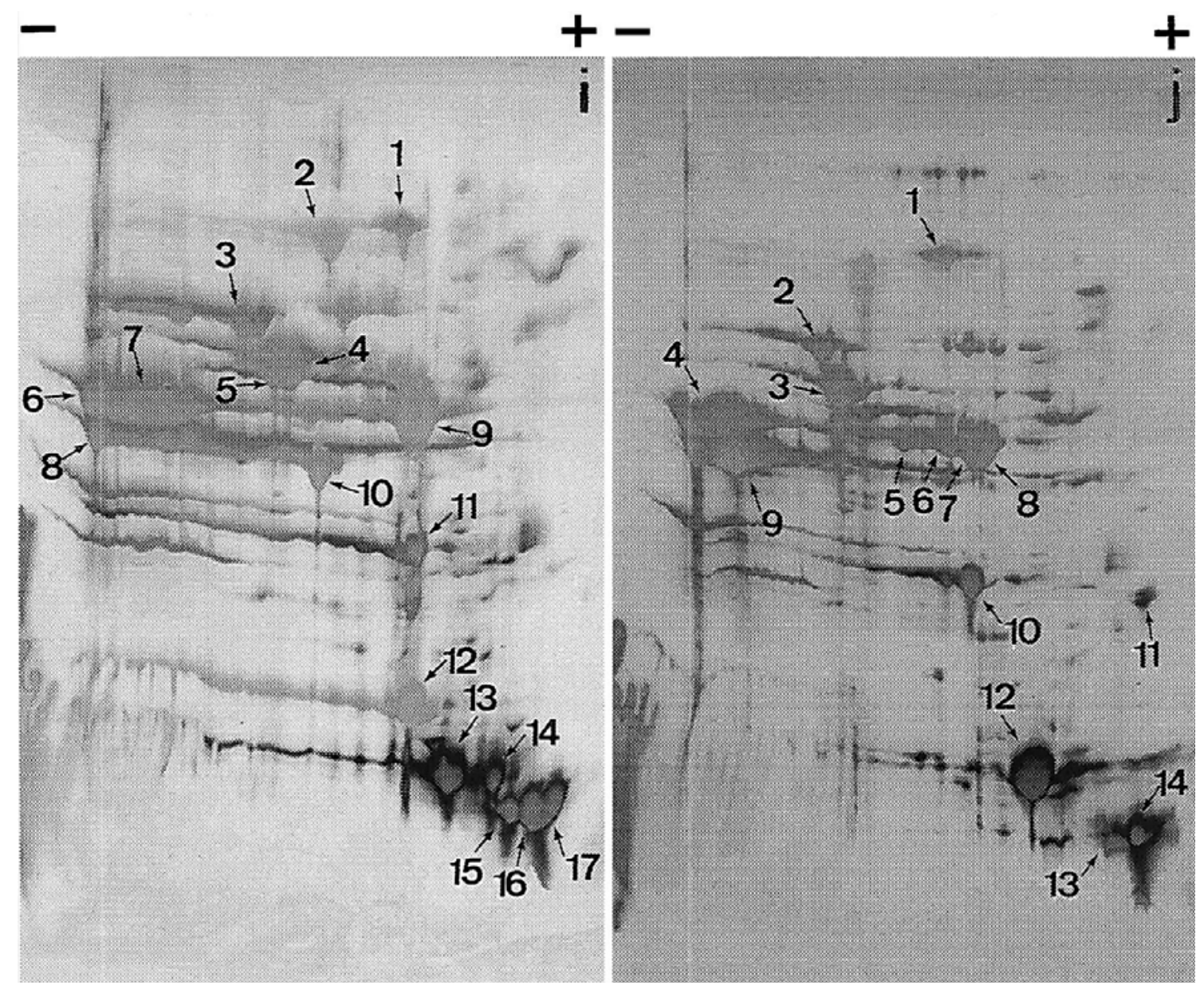

Fig. 2i-j 